\title{
MEMÓRIA INFIEL
}

\author{
JULES SUPERVIELLE*
}

TRADUÇÃo DE MARLOVA ASEFF

[*] Nascido em Montevidéu, em 1884 , o poeta Jules Supervielle "francês do Uruguai, era afinal um vizinho nosso que levou para a Europa alguma coisa da América" (Drummond) - formou, ao lado de Jules Laforgue e Isidore Ducasse, a grande trinca de poetas franco-uruguaios. Morreu em Paris, em 1960. O livro Oublieuse mémoire é de 1949.
I

Pálido sol de olvido, lua fria da memória, Que sugas tu ao fundo de teu calado mundo? É este o pouco então que ofereces, simplórias Gotas d'água, somente este vinho infecundo?

Então, que farás tu deste dia de calor

Tu que me alteras tudo que ainda não é dor?

Bem, não devolvas tal como um dia te dei

Este ar tão precioso, as pessoas que amei.

Que moldam os meus dias tua luz e tuas mãos, Refaz por sobre mim as vias dos que virão, Leva meu coração por campos de vertigem Onde até o gramado duvida de sua origem.

Mas eu de que reclamo, ó leve reviver...

Quem teve sede? Quem não queria beber?

\section{II}

Repare, sob meus olhos tudo muda de cor, E o prazer se estilhaça em pedaços de dor, Não ouso mais abrir o escaninho escondido Que à minha memória tem sempre confundido.

Eu lhe ofereço um galho, ela faz uma nave, Eu lhe ofereço um rosto, ela faz uma ave, Eseé uma ave, a transforma em abelhas, Te quero sobre a terra, pelos ares centelhas! 
Retiro-te da cama, já estás bem distante, Escondo-te num canto e tu arrombas a porta,

Tenho-te contra mim, és não mais que uma morta,

Desejo-te em silêncio, tu cantas saltitante.

Que fizeste da torre que um dia eu te dei

E que fez da afeição teu coração sem lei?

III

Mas com tanto esquecer, como se faz a rosa,

Com tantas despedidas, como irei retornar,

Mil pássaros em fuga, nenhum por aqui pousa

Em tanta escuridão, mal pode o dia vingar.

Escute, aproxime sua sombria face,

Libere sem temor as asas do coração

E na sombra por fim sua memória renasce,

E o mundo nos devolve as cores como são

O tronco seco brota, e a nascente transborda

E eis então este lago sob olhos espantados?

Que até o firmamento sei que a terra recorda

E renasce por quem se cria renegado!

Memória, irmã obscura que olho na face,

Desde que me permita uma imagem que passe...

IV

Sonharei minha vida semelhante à dos rios

Vivendo fonte e mar num único e só tempo

Sem poder me prender nem sequer um momento

Entre morros, planícies e córregos tardios

Estou cá, estou lá? Minha orla contumaz

Muda de lado a outro e abandona-me errante;

Sou água que desliza, nadador da vazante

Atordoado por tudo que fica para trás?

Ou serei mesmo eu que ainda sem saber

Aquele que à noite torna-se recorrente

Ao buscar o oceano do lado da nascente

Pois atrás dele está o melhor do querer? 
OUbLieuse MÉmoire

I

Pâle soleil d'oubli, lune de la mémoire,

Que draines-tu au fond de tes sourdes contrées?

Est-ce donc là ce peu que tu donnes à boire

Ces gouttes d'eau, le vin que je te confiai?

Que vas-tu faire encor de ce beau jour d'été

Toi qui me change tout quand tu ne l'as gâté?

Soit, ne me les rends point tels que je te les donne

Cet air si précieux, ni ces chères personnes.

Que modèlent mes jours ta lumière et tes mains,

Refais par-dessus moiles voies du lendemain,

Et mène-moi le coeur dans les champs de vertige

Où l'herbe n'est plus l'herbe et doute sur sa tige.

Mais de quoi me plaignais-je, ô légère mémoire...

Qui avais soif? Quelqu'un ne voulait-il pas boire?

II

Regarde, sous mes yeux tout change de couleur Et le plaisir se brise en morceaux de douleur, Jen'ose plus ouvrir mes secrètes armoires

Que vient bouleverserma confuse mémoire.

Je lui donne une branche elle en fait un oiseau, Je lui donne un visage elle en fait un museau, Et sic'est un museau elle en fait une abeille, Je te voulais sur terre, en l'air tu t'émerveilles! 
Je te sors de ton lit, te voilà déjà loin,

Je te cache en un coin et tu pousses la porte,

Je te serrais en moi, tu n'es plus qu'une morte,

Je te voulais silence et tu chantes sans fin.

Qu'as-tu fais de la tour qu'un jour je te donnai

Et qu'a fait de l'amour ton coeur désordonné?

\section{III}

Mais avec tant d'oubli comment faire une rose, Avec tant de départ comment faire un retour, Mille oiseaux qui s'enfuient n'en font un quise pose

Ettant d'obscurité simule mal le jour.

Écoutez, rapprochez moi cette pauvre joue,

Sans crainte libérez l'aile de votre coeur

Et que dans l'ombre enfin votre mémoire joue,

Nous redonnant le monde aux actives couleurs

Le chêne redevient arbre et les ombres, plaine,

Et voicidonc ce lac sous nos yeux agrandis?

Que jusqu'à l'horizon la terre se souvienne

Etrenaisse pourceux quis'en croyaient bannis!

Mémoire, soeur obscure et que je vois de face

Autant que le permet une image qui passe...

IV

J'aurai rêvé ma vie à l'instar des rivières Vivant en même temps la source et l'océan Sans pouvoir me fixer même un mince moment Entre le mont, la plaine et les plages dernières.

Suis-je ici, suis-je là? Mes rives coutumières Changent de part et d'autre et me laissent errant; Suis-je l'eau qui s'en va, le nageurdescendant Plein de trouble pour tout ce qu'il laissa derrière?

Ou serais-je plutôtsans même le savoir Celui quidans la nuitn'a plus que la ressource De chercherl'océan du côtéde la source Puisqu'est derrière lui le meilleur de l'espoir? 